Research Article

\title{
Utilization of Modified Zeolite as Catalyst for Steam Gasification of Palm Kernel Shell
}

\author{
Joko Waluyo',"*, Petric Marc Ruya ${ }^{2}$, Dwi Hantoko³, Jenny Rizkiana ${ }^{2}$, I.G.B.N. Makertihartha², \\ Mi Yan ${ }^{3}$, Herri Susanto 2
}

${ }^{1}$ Department of Chemical Engineering, Universitas Sebelas Maret, Surakarta, Indonesia.

${ }^{2}$ Department of Chemical Engineering, Institut Teknologi Bandung, Bandung, Indonesia.

${ }^{3}$ Institute of Energy and Power Engineering, Zhejiang University of Technology, Hangzhou, China.

Received: $16^{\text {th }}$ April 2021; Revised: 14th June 2021; Accepted: $14^{\text {th }}$ June 2021

Available online: 23rd June 2021; Published regularly: September 2021

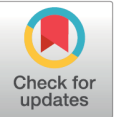

\section{Abstract}

Syngas from biomass gasification is being developed for alternative feedstock in the chemical industry. Palm kernel shell which is generated from palm oil industry can be potentially used as raw material for gasification process. The purpose of this study was to investigate the use of modified natural zeolite catalysts in steam gasification of palm kernel shells. Mordenite type zeolite was modified by acid leaching to be used as a tar cracking catalyst. Steam gasification was conducted at the temperature range of $750-850{ }^{\circ} \mathrm{C}$ and the steam to biomass ratio was in the range of $0-2.25$. The result showed that steam gasification of palm kernel shell with the addition of zeolite catalyst at $750{ }^{\circ} \mathrm{C}$ and steam to biomass ratio 2.25 could reduce tar content up to $98 \%$ or became $0.7 \mathrm{~g} / \mathrm{Nm}^{3}$. In this study, gasification of palm kernel shells produced syngas with the hydrogen concentration in the range of $52-$ $64 \%$ and $\mathrm{H}_{2} / \mathrm{CO}$ ratio of $2.7-5.7$.

Copyright (C) 2021 by Authors, Published by BCREC Group. This is an open access article under the CC BY-SA License (https://creativecommons.org/licenses/by-sa/4.0).

Keywords: Gasification; Tar Removal; Clean Syngas; Mordenite; Palm Kernel Shells

How to Cite: J. Waluyo, P.M. Ruya, D. Hantoko, J. Rizkiana, I.G.B.N. Makertihartha, M. Yan, H. Susanto. (2021). Utilization of Modified Zeolite as Catalyst for Steam Gasification of Palm Kernel Shell. Bulletin of Chemical Reaction Engineering \& Catalysis, 16(3), 623-631 (doi:10.9767/bcrec.16.3.10837.623-631)

Permalink/DOI: https://doi.org/10.9767/bcrec.16.3.10837.623-631

\section{Introduction}

Biomass gasification is a thermochemical conversion technology that converts biomass into combustible gases by the use of gasifying agents such as air, steam, $\mathrm{O}_{2}, \mathrm{CO}_{2}$ or its combination. The product gas can be used for electricity production, and also as a raw material for the chemical synthesis, such as ammonia, methanol, Fischer Tropsch Fuels, and dimethyl ether [1]. However, product gas from gasification process contains contaminant, such as tar, particulate, ammonia, hydrogen sulphide, etc. [2].

* Corresponding Author.

Email: jokowaluyo@staff.uns.ac.id (J. Waluyo);

Telp: +62-271-632112, Fax: +62-271-632112
Thus, the syngas cleaning is needed before the application of syngas. Tar is one of the contaminants that requires more attention on the biomass gasification derived gas.

Tar from the gasification process can cause plugging at lower temperature and also poison catalyst used during chemicals synthesis, which results in various problems during the operation and maintenance of the gasification process $[3,4]$. Therefore, there is a need for the attempt to reduce or eliminate the presence of tar. Tar is conventionally removed by physical treatment such as a wet scrubber where syngas temperature decreases and cause considerable wastewater. This could reduce the energy efficiency of the gasification process [5]. Thus, the 
proposed tar removal process should be designed not only to eliminate tar, but also to convert tar into syngas, so the negative impact of the waste on the environment could be minimized. Catalytic steam reforming is predicted to be a suitable process in regards to achieve the previously mentioned results.

Twin fluidized bed has been claimed to be capable of producing syngas with low tar and high hydrogen content $[6,7]$. Twin fluidized bed with steam as gasifying agent produces $\mathrm{H}_{2} / \mathrm{CO}$ ratio $>1$ and $\mathrm{H}_{2}$ concentration more than $50 \%$. Updraft gasifiers generally produce the largest amounts of tar, approximately 30-150 gram $/ \mathrm{Nm}^{3}$, followed by a downdraft and fluidized bed gasifier, at 0.01-6 gram $/ \mathrm{Nm}^{3}$ and $4-20$ gram $/ \mathrm{Nm}^{3}$, respectively [8]. The fluidized bed gasification technology utilizes sand as the heating medium. Utilization of silica sand results in relatively high tar content in the product gas, and thus another material, preferably also functioning as tar cracking catalyst should be adopted. One way of achieving the desired process would be to use natural minerals that can be utilized as tar cracking catalyst. The development of natural mineral based catalyst is currently being carried out by several researchers, among which dolomite, olivine, ilminite, limonite, calcite, polygorskite, perovskite, which are adjusted with the available minerals in the respective region [9-15]. Dolomite achieves high activity in tar conversion but is a fragile material, while olivine has high attrition resistance but lower catalytic activity compared to dolomite [16]. Zeolite is an alumina-silica mineral that has been widely used as a cracking catalyst and adsorbent [17]. Besides having high activity in cracking, zeolites can be obtained synthetically or naturally. Natural zeolites have disadvantages because they have some impurities and low surface area. Therefore, natural zeolites need to be modified to increase their activity [18]. Natural zeolites contain some impurities which can be removed by ion exchange and acid leaching. Acid leaching is also used to increase the $\mathrm{Si} / \mathrm{Al}$ ratio of zeolites, so more active and increase resistance.

The current study concerns the development of natural zeolite-based catalyst. Natural zeolite possesses various crystalline phases; among which mordenite, clinoptilolite, and mesolite are the more commonly applied types for catalysis purpose [19,20]. In a previous study, natural zeolite activity was tested in toluene steam reforming as a tar model and gave high activity results $[21,22]$. In the current study, zeolites are used for catalytic steam gasification of palm kernel shells. Increasing world palm oil production, palm kernel shells will be predicted to become significant solid waste in the future [23,24]. This research provides novel results and information regarding the conversion of palm kernel shells to syngas with a high $\mathrm{H}_{2} / \mathrm{CO}$ ratio and low tar content using natural zeolites as a catalyst. The natural zeolite was modified to improve its catalyst activity. Furthermore, the natural catalyst is directly applied in the gasification of palm kernel shells to lower the tar content in syngas, which is closer to the actual or real condition of biomass gasification. The application of natural catalyst for catalytic cracking of tar derived from gasification is also much beneficial compared to the catalytic cracking of model tar. In addition to investigating the effect of modified zeolite catalyst, this study also investigates the effect of the steam to biomass ratio, temperature of gasification on the syngas concentration, tar conversion and carbon conversion.

\section{Materials and Methods}

\subsection{Catalyst Modification and Characterization}

Natural zeolite which is used as raw material is obtained from Wonosari - Indonesia, with a size of $5-10$ mesh. $\mathrm{NH}_{4} \mathrm{NO}_{3}$ and $\mathrm{HNO}_{3}$ solutions are used as ion exchange and acid leaching agents to remove some impurities. $\mathrm{NH}_{4} \mathrm{NO}_{3}$ and $\mathrm{HNO}_{3}$ were purchased from Merck. Natural zeolites are washed and then dried. Modification was done in 2 steps, ion exchange and acid leaching. In ion exchange, every 1 gram of sample was stirred and refluxed with $10 \mathrm{~mL} 2$ $\mathrm{M} \mathrm{NH} \mathrm{NO}_{3}$ at $90{ }^{\circ} \mathrm{C}$ for 2 hours. The sample was then washed and followed by calcination at $550{ }^{\circ} \mathrm{C}$ for 12 hours to remove $\mathrm{NH}_{3}$. Acid leaching was carried out by reflux using $6 \mathrm{M}$ $\mathrm{HNO}_{3}$ at $90{ }^{\circ} \mathrm{C}$ for 6 hours (ZA-66). At the end of the modification, the sample was washed and calcined at $550{ }^{\circ} \mathrm{C}$ for 12 hours. Ni/Zeolite (ZNi-665 and ZNi-6610) catalyst was prepared by impregnation of modified zeolite with solution of $\mathrm{Ni}\left(\mathrm{NO}_{3}\right)_{2} .6 \mathrm{H}_{2} \mathrm{O}$ in an appropriate concentration to obtain a contents of 5 or $10 \mathrm{wt} \%$ of $\mathrm{NiO}$. After impregnation, the catalysts were dried at $105{ }^{\circ} \mathrm{C}$ for 6 hours and continued to be calcined at $550{ }^{\circ} \mathrm{C}$ for 3 hours using temperature increasing rate $5{ }^{\circ} \mathrm{C} / \mathrm{min}$.

The sample pulverized into powder to characterized morphology structure and pore structure. The diffraction pattern of the catalyst was measured by XRD 6000 (Shimadzu, Japan) and recorded over $2 \theta$ ranged from $5^{\circ}-60^{\circ}$ with speed of $76.8^{\circ} \mathrm{minutes}$ and step size of 0.019. The Scanning Electron MicroscopyEnergy Dispersive X-ray (SEM-EDX, FEI 
Quanta 200 ESEM FEG) (Oxford instruments Inc., Abingdon, United Kingdom) and X-ray fluorescence (XRF, Epsilon 3, United Kingdom) were used to quantify the elemental component and $\mathrm{Si} / \mathrm{Al}$ ratio of modified zeolite. For surface and pore structure, liquid nitrogen absorption

Table 1. Proximate and ultimate analysis of palm kernel shell.

\begin{tabular}{lcc}
\hline \multicolumn{3}{l}{ Characterization of palm kernel shell } \\
\hline 1 & Proximate analysis (adb) (\%wt) \\
& Moisture & 8.19 \\
& Volatile matter & 70.45 \\
& Fixed Carbon & 18.89 \\
& Ash & 2.47 \\
\hline 2 & Ultimate Analysis (adb) (\%wt) \\
& Carbon & 48.25 \\
& Hydrogen & 6.41 \\
& Oxygen & 42.69 \\
& Nitrogen & 0.15 \\
& Sulfur & 0.03 \\
\hline 3 & Heating value $(\mathrm{kJ} / \mathrm{kg})$ & 19,820 \\
\hline
\end{tabular}

was measured at $77.35 \mathrm{~K}$ using Nova 3200e, United States. The Brunauer-Emmet-Teller (BET) method used to measure surface area and pore volume.

\subsection{Biomass Gasification}

Palm kernel shell was obtained from a palm oil mill located in Lampung, Indonesia. The proximate and ultimate of palm kernel shell are presented in Table 1. The palm kernel shell goes through size reduction to the size of about $5 \mathrm{~mm}$. The palm kernel shell was dried in the oven at $105{ }^{\circ} \mathrm{C}$ for 6 hours to remove unbounded air. The modified zeolite catalyst was prepared by ion exchange and acid washing. The detailed explanation can be found in our previous study $[21,22]$. The properties of modified zeolite catalyst are presented in Table 2 .

Biomass gasification was conducted under atmospheric pressure in tubular furnace. The experimental set up is shown in Figure 1. In each experiment, 4 grams of palm kernel shell was loaded with the ratio of biomass to catalyst of 1:1. The flow rate of $\mathrm{N}_{2}$ was set at 200

Table 2. Modified Natural Zeolite.

\begin{tabular}{lccccc}
\hline Catalyst & $\begin{array}{c}\text { Acid leaching Conc. } \\
\mathrm{HNO}_{3}(\mathrm{M})\end{array}$ & $\begin{array}{c}\text { Leaching time } \\
(\mathrm{hr})\end{array}$ & Ni Impregnation & Si/Al ratio* & $\begin{array}{c}\text { Surface area } \\
\left(\mathrm{m}^{2} / \mathrm{g}\right)\end{array}$ \\
\hline ZA0 & - & - & - & 5.09 & 16 \\
ZA66 & 6 & 6 & - & 5.61 & 161.8 \\
ZNi-665 & 6 & 6 & $5 \%$ & 5.31 & 73.5 \\
ZNi-6610 & 6 & 6 & $10 \%$ & 5.25 & 51.4 \\
\hline
\end{tabular}

*analyzed by XRF

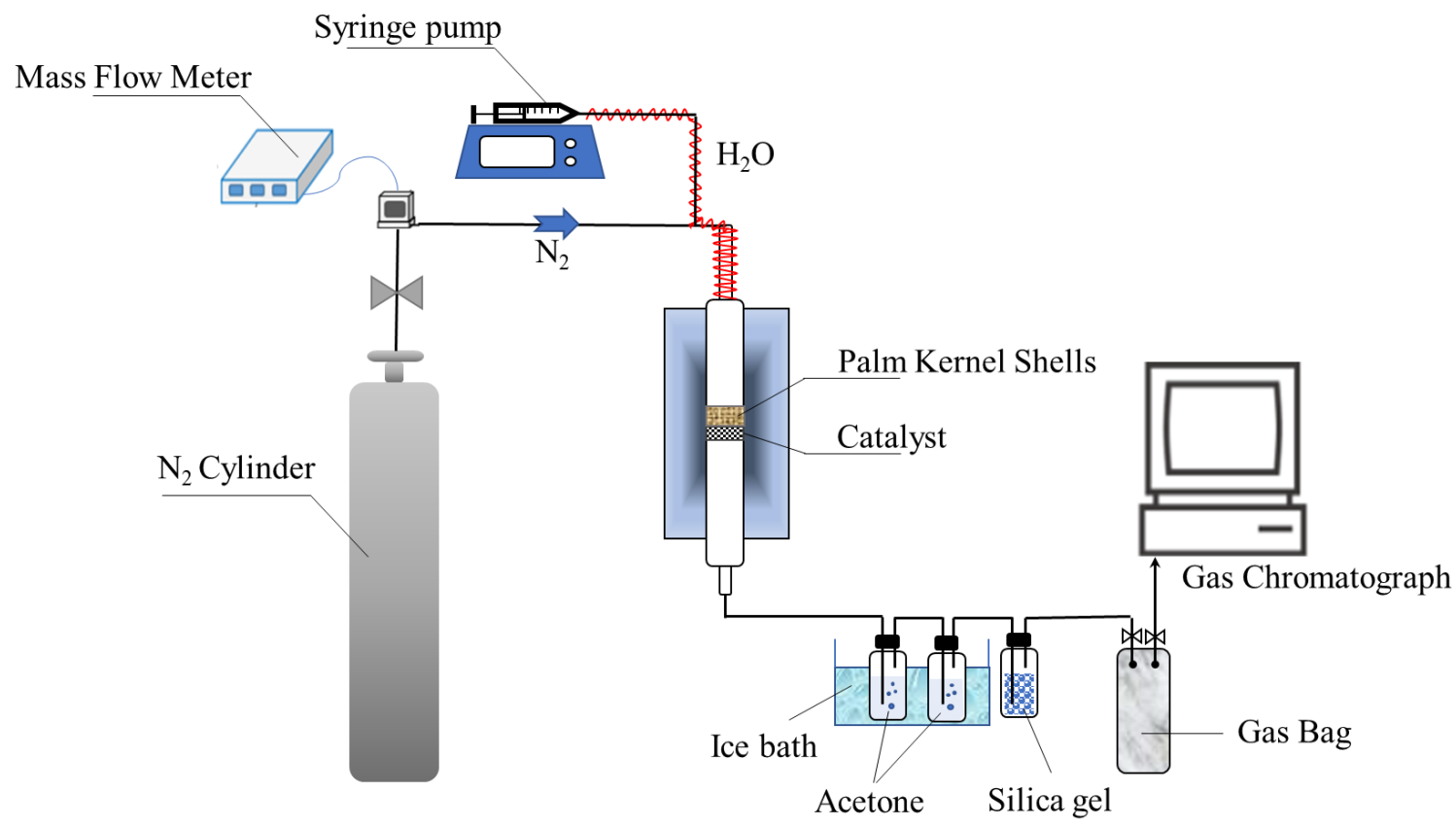

Figure 1. Experimental setup of steam gasification. 
$\mathrm{mL} / \mathrm{min}$ (at atmospheric condition). Electric heater was used to heat the reactor with the heating rate of $75{ }^{\circ} \mathrm{C} / \mathrm{min}$. When the temperature of the reactor has reached $400{ }^{\circ} \mathrm{C}$, steam was injected into the reactor until the desired temperature has been reached $\left(750{ }^{\circ} \mathrm{C}, 800^{\circ} \mathrm{C}\right.$, $850{ }^{\circ} \mathrm{C}$ ). Upon achieving the desired temperature, the temperature was kept for 30 minutes. Gasification derived tar was cooled down and then dissolved into acetone, while the gas produced was collected inside gas bag (capacity 10 Liter). Gravimetric analysis was used to determine the concentration of tar in syngas trapped in acetone. The composition/concentration of the pyrolysis and gasification product gas was analyzed using gas chromatograph (GV 2014A Shimadzu, Japan) with 2 columns (MS5A and Porapak-Q). The sample was analyzed using TCD (Thermal Conductivity Detector) at the temperature of $150{ }^{\circ} \mathrm{C}$.

Yield of the pyrolysis products (tar, char and gas) are defined as follows:

$$
Y_{\text {tar }}=\frac{w_{\text {tar }}}{w_{\text {biomass }}}
$$

Yield of the gasification product, particularly hydrogen is defined as:

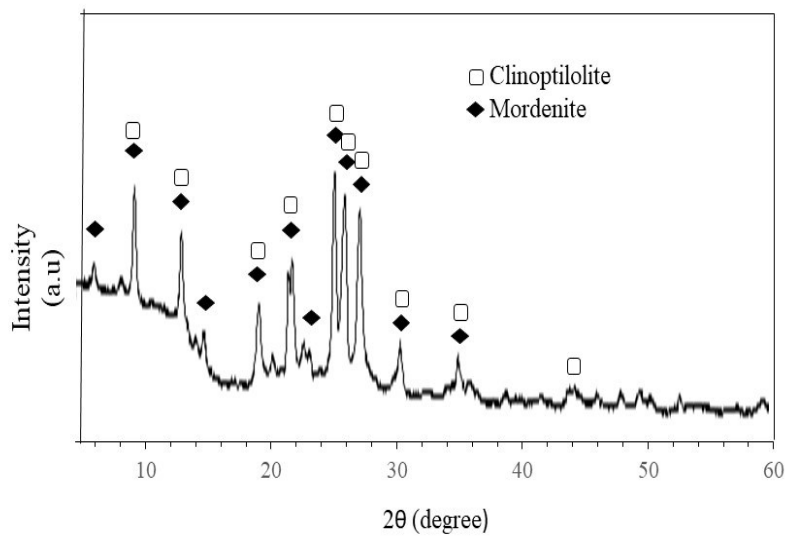

Figure 2. Natural zeolite structure.

$$
Y_{H_{2}}=\frac{n_{H_{2}}}{w_{\text {biomass }}}
$$

Mol of $\mathrm{H}_{2}$ was calculated by using the following equation

$$
n_{H_{2}}=\frac{\left[\begin{array}{c}
\text { Flowrate of } \\
\text { Nitrogen }
\end{array}\right] \times\left[\begin{array}{c}
\text { Collection } \\
\text { time }
\end{array}\right]}{\left[\begin{array}{c}
\text { Concentration of } \\
\text { Nitrogen }
\end{array}\right]} \times\left[\begin{array}{c}
\text { Concentration of } \\
\text { Hydrogen }
\end{array}\right]
$$

For mol of $\mathrm{CO}, \mathrm{CO}_{2}, \mathrm{CH}_{4}$ follow the Equation (3) by substituting the appropriate gas concentration.

Meanwhile, the potential yield of $\mathrm{H}_{2}$ that can be obtained from the presence of $\mathrm{CO}$ from the composition of syngas. This may be due to the water gas shift reaction involving $\mathrm{CO}$ that is mild exothermic and relatively easy to perform:

$$
Y_{\mathrm{H}_{2}+\mathrm{CO}}=\frac{n_{\left(\mathrm{H}_{2}+\mathrm{CO}\right)}}{w_{\text {biomass }}}
$$

Biomass carbon conversion is defined as:

$$
X_{C}=\frac{n_{\left(\mathrm{CO}+\mathrm{CO}_{2}+\mathrm{CH}_{4}\right)}}{n_{\text {Carbon in biomass }}} \times 100 \%
$$

\section{Results and Discussion}

The composition and yield of syngas from biomass conversion is affected by several factors, namely temperature and the ratio of steam/biomass. Aside from the yield, carbon conversion will also be discussed in this section. The carbon conversion is the number of gaseous products obtained from $\mathrm{CO}, \mathrm{CO}_{2}$, and $\mathrm{CH}_{4}$ as compared to the carbon (C) from biomass. The presence of catalyst on the gasification process can improve the carbon conversion with regard to the increase in the $\mathrm{CO}, \mathrm{CO}_{2}$ and $\mathrm{CH}_{4}$ concentration (obtained due to the conversion of gasification derived tar into smaller component/syngas). In this sub-chapter characterization of catalyst, effect of catalyst type, ra-

Table 3. Zeolite composition as determined using EDX analysis.

\begin{tabular}{cccccc}
\hline No & Element & Fresh Zeolite & $\begin{array}{c}\text { After acid leaching } \\
\text { (ZA-66) }\end{array}$ & $\begin{array}{c}\text { After impregnation } \\
\text { Ni 5\% }\end{array}$ & $\begin{array}{c}\text { After impregnation } \\
\text { Ni 10\% }\end{array}$ \\
\hline 1 & $\mathrm{C}$ & 0 & 5.68 & 4.24 & 3.84 \\
2 & $\mathrm{O}$ & 55.02 & 51.21 & 50.2 & 45.53 \\
3 & $\mathrm{Na}$ & 0.72 & 0.22 & 0.19 & 0.32 \\
4 & $\mathrm{Mg}$ & 0.87 & 0.53 & 0.36 & 0.36 \\
5 & $\mathrm{Al}$ & 7.09 & 7.23 & 6.30 & 6.28 \\
6 & $\mathrm{Si}$ & 30.47 & 31.48 & 31.01 & 30.61 \\
7 & $\mathrm{~K}$ & 0.65 & 0 & 0 & 0 \\
8 & $\mathrm{Ca}$ & 3.06 & 1.72 & 1.65 & 1.67 \\
9 & $\mathrm{Ti}$ & 0.27 & 0.27 & 0 & 0.19 \\
10 & $\mathrm{Fe}$ & 2.57 & 1.65 & 0.72 & 1.36 \\
11 & $\mathrm{Ni}$ & 0 & 0 & 5.34 & 9.82 \\
\hline
\end{tabular}


tio of steam/biomass along with the gasification temperature on the composition and yield of tar is discussed.

\subsection{Characterization of Catalyst}

XRD results (Figure 2) show that Indonesia's natural zeolites consist of mordenite and clinoptilolite as the main components. The stage comparison is based on the ICDD (International Center for Diffraction Data) database. The diffraction results also showed that natural zeolites still contained impurities, in line with the results of component analysis using SEM-EDX (Table 3). Some of the impurities contained are alkaline and alkaline earth metals, such as: $\mathrm{Na}, \mathrm{K}, \mathrm{Mg}$, Ca. These impurities can cover the pores and active sites of zeolites which can reduce zeolite activity. After modification by acid washing some of these impurities were reduced (Table 3 and Figure 3). In this study, the zeolite from acid washing was further modified with $\mathrm{Ni}$ impregnation to determine the effect of the addition of $\mathrm{Ni}$ on the zeolite on catalyst activity.

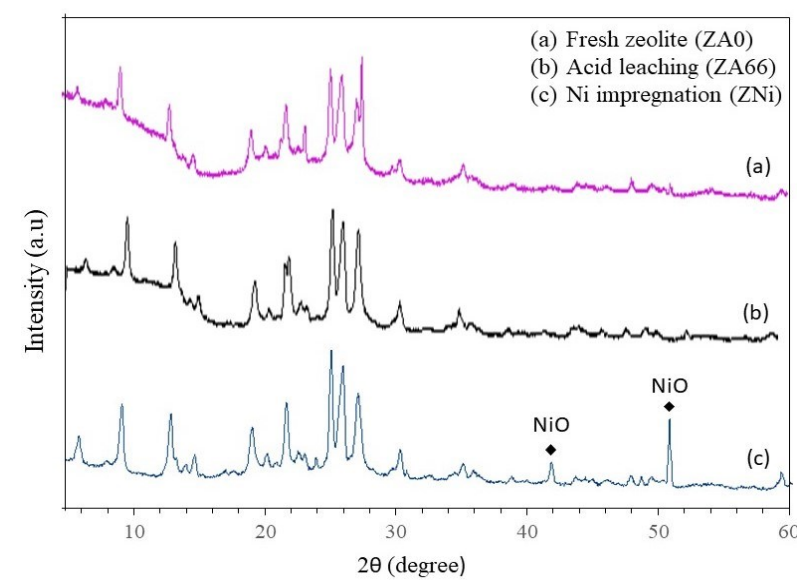

Figure 3. XRD pattern of modified zeolite.

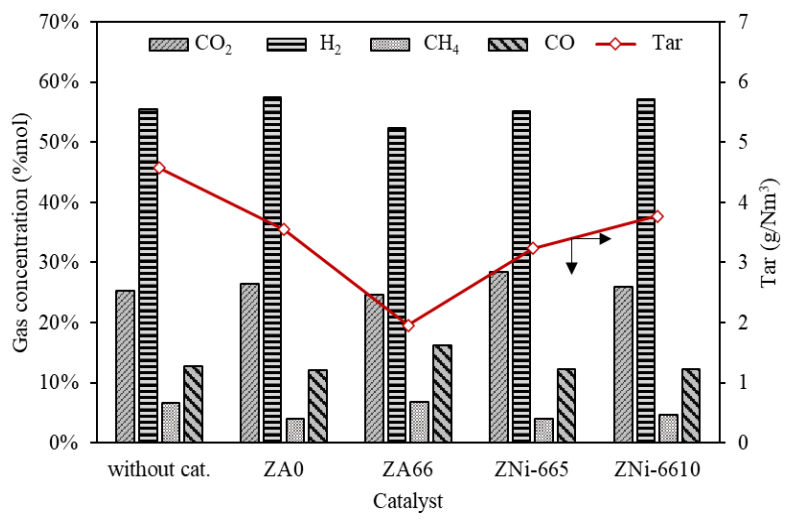

Figure 4. Effect of catalyst on syngas and tar concentration at $750{ }^{\circ} \mathrm{C}$ and steam/biomass ratio of 1.5.
The dealumination of natural zeolites using acid leaching generally had a negligible effect on the crystallinity as the characteristic peaks remain unchanged unless a small reduction in intensity. Figure 3 shows that small peaks at $2 \theta$ of $23^{\circ}, 26.5^{\circ}$, and $29.5^{\circ}$ have declined in intensity. The zeolite modification by acid leaching apart from reducing impurities also increased the $\mathrm{Si} / \mathrm{Al}$ ratio and increased the surface area.

\subsection{Effect of Catalyst Type}

In previous studies, zeolites from Wonosari are mordenite type zeolite and after modification by ion exchange and acid leaching, impurities in zeolites such as $\mathrm{Na}, \mathrm{K}, \mathrm{Mg}$ can be removed. Impurity loss also has a positive impact on increasing surface area and pore volume [21]. In this study, the catalysts employed were the previously developed catalysts which has been tested using tar model component [22]. The modified zeolite catalyst was tested to determine the effect of catalyst to the syngas concentration, the yield of each syngas component, as well as carbon conversion, which represents the amount of reacted biomass and also the amount of reacted tar. The test was conducted at $750{ }^{\circ} \mathrm{C}$, the ratio of catalyst to biomass is taken as $1: 1$, the ratio of steam to biomass taken as 1.5:1, and the flowrate of $\mathrm{N}_{2}$ of 200 $\mathrm{mL} /$ hour.

The presence of catalyst did not affect the syngas composition significantly (Figure 4), however tar concentration decreased from 4.6 $\mathrm{g} / \mathrm{Nm}^{3}$ to $1.9 \mathrm{~g} / \mathrm{Nm}^{3}$ with the presence of ZA66 catalyst. In other words, the application of ZA66 catalyst reduced the tar content by $57 \%$. When the gasification was conducted for 30 minutes, the effect of the catalyst on the syngas yield and carbon conversion can be ob-

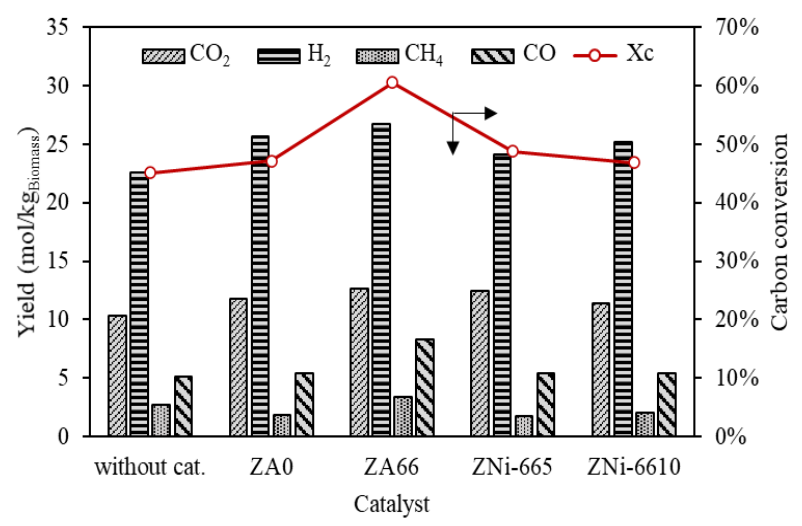

Figure 5. Effect of catalyst on the syngas yield and carbon conversion at $750{ }^{\circ} \mathrm{C}$ and steam/biomass ratio of 1.5 . 
served. From Figure 5, the presence of the modified zeolite catalyst ZA66 increased the syngas yield as compared to when unmodified zeolite, without the addition of Nickel active phase, was used. This was due to the ZA66 catalyst having the largest surface area as compared to other catalysts. This is in line with the results of XRD and EDX that the acid leaching process has reduced impurities, such as: $\mathrm{Na}, \mathrm{K}, \mathrm{Ca}$, and $\mathrm{Mg}$, thereby increasing the activity of the catalyst. The nickel $(\mathrm{NiO})$ impregnated zeolite catalyst remains inactivate/unreduced due to the short gasification time (30 minutes). This was different with the experiment that used toluene as tar model where the reaction was conducted for 8 hours and nickel oxide has been reduced [22]. The usage of nickel doped catalyst is not suitable as both catalyst and heating media on twin fluidized bed gasifier. The nickel catalyst is only suitable to be used on secondary tar reaction mode (steam reforming reactor on a separate unit after the gasifier).

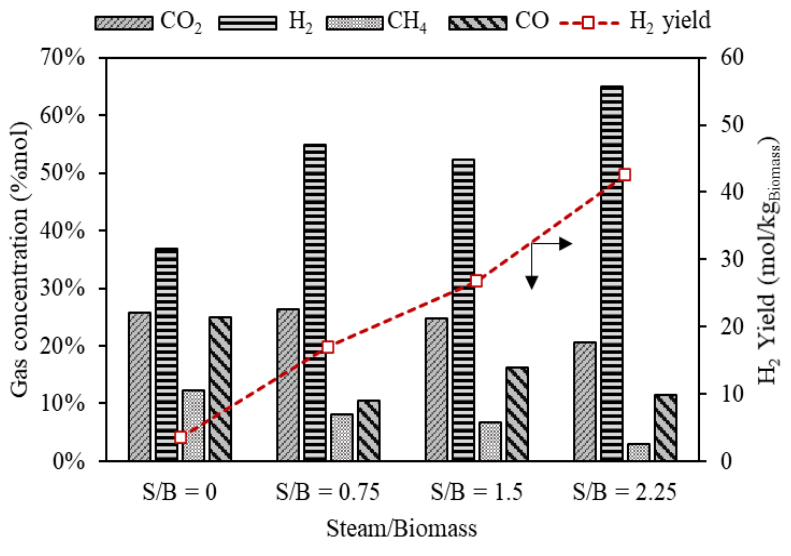

Figure 6. Effect of steam to biomass ratio on $\mathrm{H}_{2}$ concentration and $\mathrm{H}_{2}$ yield at $750{ }^{\circ} \mathrm{C}$ with the addition of ZA66 catalyst.

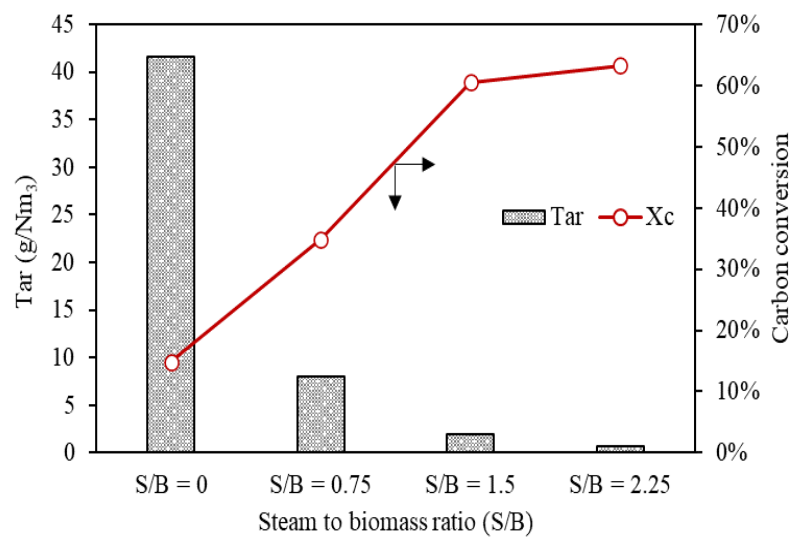

Figure 7. Effect of steam to biomass ratio on tar concentration and carbon conversion at $750{ }^{\circ} \mathrm{C}$ with the addition of ZA66 catalyst.
The utilization of ZA66 could increase the syngas yield from a total of $41 \mathrm{~mol} / \mathrm{kg}_{\text {biomass }}$ to $51 \mathrm{~mol} / \mathrm{kg}_{\text {biomass. }}$ The carbon conversion also increased from $45 \%$ to $61 \%$. The increase in syngas yield and carbon conversion indicated that tar underwent cracking or reforming reaction to produce syngas. On the subsequent experiments to observe the effect of steam to biomass ratio and gasification temperature, ZA66 catalyst was used.

\subsection{The Effect of Steam to Biomass Ratio}

Gasification with steam medium is required in the production of $\mathrm{H}_{2}$ rich syngas. In this study, the ratio of steam to biomass was varied in the range of 0 to 2.25 as presented in Figure 6 . When the steam to biomass ratio was 0.75 , the $\mathrm{H}_{2}$ concentration increased by $18 \% \mathrm{~mol}$ $(54.9 \% \mathrm{~mol})$ and $\mathrm{H}_{2}$ yield increased 4.9 -fold (17 $\mathrm{mol} / \mathrm{kg}_{\text {biomass }}$ ) as compared to when no steam (pyrolysis with ZA66 catalyst). The highest $\mathrm{H}_{2}$ concentration and yield was obtained when the steam to biomass ratio was 2.25 with the $\mathrm{H}_{2}$ concentration of $65 \%$ and $\mathrm{H}_{2}$ yield of 42.6 $\mathrm{mol} / \mathrm{kg}$ biomass. On the process without steam (pyrolysis with ZA66 catalyst), the tar concentration was $41.7 \mathrm{~N} / \mathrm{m}^{3}$, while when the steam to biomass (S/B) ratio was 2.25 , the tar concentration was $0.72 \mathrm{~g} / \mathrm{Nm}^{3}$ (98\% tar conversion upon increasing the steam flowrate), as presented in Figure 7.

As the steam to biomass ratio increased, the concentration of $\mathrm{H}_{2}$ also increased, while the concentration of $\mathrm{CH}_{4}$ decreased. This indicated the occurrence of steam reforming reaction on tar and light hydrocarbons $\left(\mathrm{CH}_{4}\right)$, and water gas shift. Aside from that, the operating condition will be more profitable if the concentration of $\mathrm{H}_{2}$ was high and the concentration of $\mathrm{CO}_{2}$

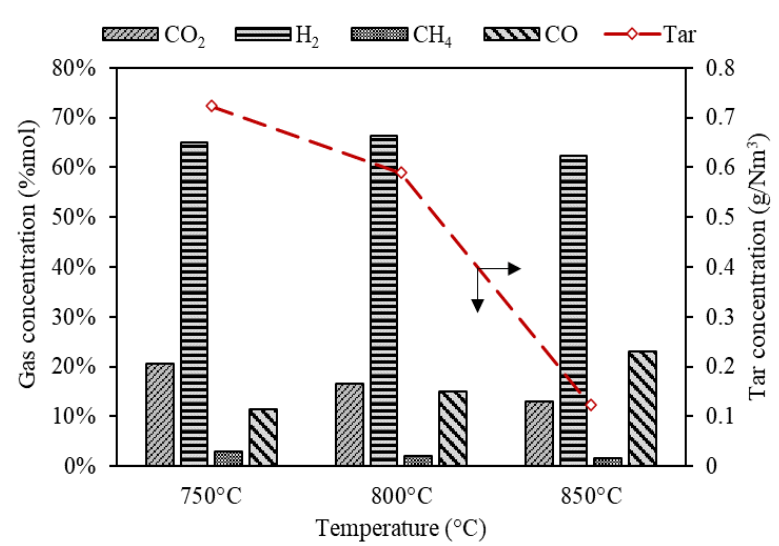

Figure 8. Effect of temperature on the gas concentration and tar concentration at $\mathrm{S} / \mathrm{B}$ of 2.25 with the addition of ZA66 catalyst. 
was kept as low as possible. This was acquired at the steam to biomass ratio of 2.5. Therefore, the variation of reaction temperature used the steam to biomass ratio of 2.5 . The disadvantage of increasing steam utilization would be the increased requirement for energy.

\subsection{Effect of Gasification Temperature}

The $\mathrm{H}_{2}$ concentration as well as the $\mathrm{H}_{2} / \mathrm{CO}$ ratio on the gasification process is affected by the gasification temperature. Palm kernel shell gasification was conducted at the temperature varied from 750 to $850{ }^{\circ} \mathrm{C}$ using the ZA66 catalyst. The steam to biomass ratio used was 2.25 and the gasification was conducted for 30 minutes. The effect of gasification temperature on the syngas composition is presented on Figure 8 and Table 4.

In the palm kernel shell biomass gasification as the temperature increased, the yield of $\mathrm{H}_{2}$ and its potential yield also increased. This was due to the main gasification reactions, such as water gas (6-7), Boudouard (8), and steam reforming (9) being endothermic reaction, which is favored at higher temperature. The $\mathrm{CO}$ yield and carbon conversion increased with increasing temperature, while the $\mathrm{CO}_{2}$ yield decreased. This was due to the water gas and Boudouard reaction, both of which were endothermic reaction, being more dominant at higher temperature.

$$
\begin{array}{ll}
\text { Water gas: } & \\
\mathrm{C}+\mathrm{H}_{2} \mathrm{O} \leftrightarrow \mathrm{H}_{2}+\mathrm{CO} & +131 \mathrm{~kJ} / \mathrm{mol} \\
\text { Water gas: } & \\
\mathrm{C}+2 \mathrm{H}_{2} \mathrm{O} \leftrightarrow 2 \mathrm{H}_{2}+\mathrm{CO}_{2} & +90 \mathrm{~kJ} / \mathrm{mol} \\
\text { Boudouard: } & \\
\quad \mathrm{C}+\mathrm{CO}_{2} \leftrightarrow 2 \mathrm{CO} & +172 \mathrm{~kJ} / \mathrm{mol} \\
\text { Steam reforming: } & \\
\mathrm{CH}_{4}+\mathrm{H}_{2} \mathrm{O} \leftrightarrow 3 \mathrm{H}_{2}+\mathrm{CO} & +206 \mathrm{~kJ} / \mathrm{mol}
\end{array}
$$

\begin{tabular}{|c|c|c|c|c|}
\hline \multirow{2}{*}{ No } & \multirow{2}{*}{ Parameter } & \multicolumn{3}{|c|}{ Temperature $\left({ }^{\circ} \mathrm{C}\right)$} \\
\hline & & 750 & 800 & 850 \\
\hline \multirow[t]{5}{*}{1} & Gas composition (\%mol) & & & \\
\hline & $\mathrm{H}_{2}$ & 65.02 & 66.27 & 62.37 \\
\hline & $\mathrm{CO}$ & 11.40 & 14.97 & 22.95 \\
\hline & $\mathrm{CH}_{4}$ & 2.94 & 2.09 & 1.71 \\
\hline & $\mathrm{CO}_{2}$ & 20.65 & 16.67 & 12.97 \\
\hline 2 & Tar concentration $\left(\mathrm{g} / \mathrm{Nm}^{3}\right)$ & 0.72 & 0.59 & 0.12 \\
\hline 3 & Heating value $\left(\mathrm{MJ} / \mathrm{Nm}^{3}\right)$ & 10.89 & 11.17 & 11.52 \\
\hline 4 & $\mathrm{H}_{2} / \mathrm{CO}$ ratio $(\mathrm{mol} / \mathrm{mol})$ & 5.71 & 4.43 & 2.72 \\
\hline 5 & $\mathrm{H}_{2} / \mathrm{CO}_{2}$ ratio $(\mathrm{mol} / \mathrm{mol})$ & 3.15 & 3.98 & 4.81 \\
\hline \multirow[t]{5}{*}{6} & Syngas yield (mol/kg biomass) & & & \\
\hline & $\mathrm{H}_{2}$ & 42.60 & 51.11 & 55.85 \\
\hline & $\mathrm{CO}$ & 8.30 & 11.54 & 20.55 \\
\hline & $\mathrm{CH}_{4}$ & 2.14 & 1.61 & 1.53 \\
\hline & $\mathrm{CO}_{2}$ & 15.03 & 12.85 & 11.61 \\
\hline 7 & Yield potential (yield $\mathrm{H}_{2}+\mathrm{CO}$ ) & 50.90 & 62.66 & 76.40 \\
\hline 8 & Carbon conversion (\%) & 63.3 & 64.7 & 83.8 \\
\hline
\end{tabular}

Biomass gasification with ZA66 catalyst at steam to biomass ratio of 2.25 resulted in rela-

\begin{tabular}{|c|c|c|c|c|c|c|}
\hline Parameter & $\begin{array}{c}\text { Yusup et al. } \\
{[25]}\end{array}$ & $\begin{array}{c}\text { Chiodo } \\
{[26]}\end{array}$ & $\begin{array}{l}\text { Kimbauer } \\
\text { et al. }[27]\end{array}$ & $\begin{array}{c}\text { Zhang et al. } \\
\text { [28] }\end{array}$ & $\begin{array}{c}\text { Udomsirichakom } \\
\text { et al. }[29]\end{array}$ & This Study \\
\hline Biomass & $\begin{array}{l}\text { Palm kernel } \\
\text { shell }\end{array}$ & $\begin{array}{c}\text { Orange } \\
\text { Peel }\end{array}$ & Wood pellet & $\begin{array}{c}\text { Ficus lacor } \\
\text { leaves }\end{array}$ & Pine wood sawdust & $\begin{array}{c}\text { Palm kernel } \\
\text { shell }\end{array}$ \\
\hline S/B ${ }^{1}$ Ratio & $1.5-2.5$ & 1.5 & 1.6 & $0.5-2.5$ & 3.41 & $0.75-2.25$ \\
\hline Catalyst & $\mathrm{CaO}$ & Dolomite & Olivine & $\mathrm{CaO} / \mathrm{MgO}$ & $\begin{array}{c}\text { Silica sand and } \\
\mathrm{CaO}\end{array}$ & Natural zeolite \\
\hline Tem & $600-700^{\circ} \mathrm{C}$ & & $750-875^{\circ} \mathrm{C}$ & & $550-700^{\circ} \mathrm{C}$ & $750-850^{\circ} \mathrm{C}$ \\
\hline $\mathrm{H}_{2}(\% \mathrm{mo}$ & $78-86 \%$ & $45 \%$ & $38-43 \%$ & $45 \%$ & $45-63 \%$ & $52-64 \%$ \\
\hline $\mathrm{H}_{2} / \mathrm{CO}$ & - & $2.5-4.5$ & 1.8 & $2.5-4.5$ & 4 & $2.7-5.7$ \\
\hline $\operatorname{Tar}\left(\mathrm{g} / \mathrm{Nm}^{3}\right)$ & - & - & $0.9-3$ & & $3-100$ & $0.1-8$ \\
\hline
\end{tabular}
tively high $\mathrm{H}_{2}$ concentration which was around $64 \mathrm{~mol} \%$ and increasing the temperature from $750{ }^{\circ} \mathrm{C}$ to $850{ }^{\circ} \mathrm{C}$ could increase the carbon conversion from $63.3 \%$ to $83.8 \%$. Comparatively,

Table 4. Effect of gasification temperature using ZA66 catalyst on S/B of 2.25.

Table 5. Comparison of the effect of different catalyst on syngas composition.

${ }_{1}$ Steam to biomass ratio 
biomass gasification with ZA66 catalyst at the steam to biomass ratio of 1.5 and temperature of $750{ }^{\circ} \mathrm{C}$ increased the yield of gas with $\mathrm{H}_{2}$ composition of $52 \%$-mol. This is in accordance to the requirement, such as pure hydrogen utilization (fuel cell, ammonia synthesis) or syngas with a certain $\mathrm{H}_{2} / \mathrm{CO}$ ratio (methanol synthesis, dimethyl ether, Fischer Tropsch, etc.)

Compared to the previous work on biomass gasification, utilization of natural material, namely the natural zeolite on palm shell gasification yielded satisfactory results with regards to $\mathrm{H}_{2}$ concentration, as well as $\mathrm{H}_{2} / \mathrm{CO}$ ratio as can be seen on Table 5. The use of $\mathrm{CaO}$ in biomass gasification can increase the concentration of $\mathrm{H}_{2}$ in syngas because it can be used as a $\mathrm{CO}_{2}$ adsorbent, but the tar concentration is still high. While the use of olivine, tar concentration is quite low but also produces low hydrogen concentrations. The use of zeolite can improve the quality of syngas by increasing hydrogen concentration and eliminating tar in syngas.

\section{Conclusions}

Activation of natural zeolite by acid leaching was capable to increase zeolite activity in catalytic tar cracking. Gasification of palm kernel shells with modified natural zeolite catalyst could produce clean syngas with tar content reached $0.12 \mathrm{~g} / \mathrm{Nm}^{3}$ and the ratio of $\mathrm{H}_{2} / \mathrm{CO}$ syngas ranging from 2.7-5.7. Increasing the gasification temperature could increase the yield of hydrogen and reduce the tar concentration in syngas, but also decrease the $\mathrm{H}_{2} / \mathrm{CO}$ ratio. The syngas produced at $850{ }^{\circ} \mathrm{C}$ and steam to biomass ratio of 2.25 can be used as feedstock in chemical industry. Future studies are planned for testing the strength of the catalyst against catalyst abrasion and deactivation.

\section{Acknowledgments}

This work was supported by Capacity Building Research Group LPPM Universitas Sebelas Maret, Surakarta, Indonesia. Joko Waluyo greatly acknowledge the Ministry of Science and Technology China for Talented Young Scientist Program.

\section{References}

[1] Venvik, H.J., Yang, J. (2017). Catalysis in microstructured reactors: Short review on smallscale syngas production and further conversion into methanol, DME and Fischer-Tropsch products. Catalysis Today, 285, 135-146. DOI: 10.1016/j.cattod.2017.02.014
[2] Abdoulmoumine, N., Adhikari, S., Kulkarni, A., Chattanathan, S. (2015). A review on biomass gasification syngas cleanup. Applied Energy, 155, 294-307. D O I: 10.1016/j.apenergy.2015.05.095

[3] Anis, S., Zainal, Z.A. (2011). Tar reduction in biomass producer gas via mechanical, catalytic and thermal methods: A review. Renewable and Sustainable Energy Reviews, 15(5), 23552377. DOI: 10.1016/j.rser.2011.02.018

[4] Waluyo, J., Makertihartha, I., Susanto, H. (2018). Pyrolysis with intermediate heating rate of palm kernel shells: Effect temperature and catalyst on product distribution. AIP Conference Proceedings, 1977(1), 020026. DOI: $10.1063 / 1.5042882$

[5] Saleem, F., Harris, J., Zhang, K., Harvey, A. (2020). Non-thermal plasma as a promising route for the removal of tar from the product gas of biomass gasification - A critical review. Chemical Engineering Journal, 382, 122761. DOI: $10.1016 /$ j.cej.2019.122761

[6] Kuba, M., Kraft, S., Kirnbauer, F., Maierhans, F., Hofbauer, H. (2018). Influence of controlled handling of solid inorganic materials and design changes on the product gas quality in dual fluid bed gasification of woody biomass. Applied Energy, 210, 230-240. DOI: 10.1016/j.apenergy.2017.11.028

[7] Chen, Z., Li, Y., Lai, D., Geng, S., Zhou, Q., Gao, S., Xu, G. (2018). Coupling coal pyrolysis with char gasification in a multi-stage fluidized bed to co-produce high-quality tar and syngas. Applied Energy, 215, 348-355. DOI: 10.1016/j.apenergy.2018.02.023

[8] Ruiz, J.A., Juárez, M.C., Morales, M.P., Muñoz, P., Mendívil, M.A. (2013). Biomass gasification for electricity generation: Review of current technology barriers. Renewable and Sustainable Energy Reviews, 18, 174-183. DOI: $10.1016 /$ j.rser.2012.10.021

[9] Roche, E., de Andrés, J.M., Narros, A., Rodríguez, M.E. (2014). Air and air-steam gasification of sewage sludge. The influence of dolomite and throughput in tar production and composition. Fuel, 115, 54-61. DOI: 10.1016/j.fuel.2013.07.003

[10] Cho, M.-H., Mun, T.-Y., Choi, Y.-K., Kim, J.S. (2014). Two-stage air gasification of mixed plastic waste: Olivine as the bed material and effects of various additives and a nickelplated distributor on the tar removal. Energy, $70, \quad 128-134 . \quad$ D O I : 10.1016/j.energy.2014.03.097

[11] Kuhn, J.N., Zhao, Z., Felix, L.G., Slimane, R.B., Choi, C.W., Ozkan, U.S. (2008). Olivine catalysts for methane- and tar-steam reforming. Applied Catalysis B: Environmental, $81(1-2), \quad 14-26$. D O I : 10.1016/j.apcatb.2007.11.040 
[12] Fredrik, L., Nicolas, B., Martin, S., Henrik, T. (2013). Ilmenite and Nickel as catalysts for upgrading of raw gas derived from biomass gasification. Energy Fuels, 27 (2), 997-1007. DOI: $10.1021 / \mathrm{ef} 302091 \mathrm{w}$

[13] Liu, H., Chen, T., Chang, D., Chen, D., He, H., Frost, R.L. (2012). Catalytic cracking of tar derived from rice hull gasification over palygorskite-supported $\mathrm{Fe}$ and Ni. Journal of Molecular Catalysis A: Chemical, 363-364, 304-310. DOI: 10.1016/j.molcata.2012.07.005

[14] Oemar, U., Ang, P.S., Hidajat, K., Kawi, S. (2013). Promotional effect of Fe on perovskite LaNixFe1-xO3 catalyst for hydrogen production via steam reforming of toluene. International Journal of Hydrogen Energy, 38(14), $\begin{array}{lllllllllllllll}5 & 5 & 2 & 5 & - & 5 & 5 & 3 & 4 & \text {. } & & \text { D } & \mathrm{O} & \mathrm{I}\end{array}$ 10.1016/j.ijhydene.2013.02.083

[15] Zou, X., Chen, T., Liu, H., Zhang, P., Chen, D., Zhu, C. (2016). Catalytic cracking of toluene over hematite derived from thermally treated natural limonite. Fuel, 177, 180-189. DOI: 10.1016/j.fuel.2016.02.094

[16] El-Rub, Z.A., Bramer, E.A., Brem, G. (2004). Review Of Catalysts For Tar Elimination In Biomass Gasification Process. Induatrial \& Engineering Chemistry Research, 43, 69116919. DOI: https://doi.org/10.1021/ie0498403

[17] Wongcharee, S., Aravinthan, V., Erdei, L. (2019). Mesoporous activated carbon-zeolite composite prepared from waste macadamia nut shell and synthetic faujasite. Chinese Journal of Chemical Engineering, 27(1), 226236. DOI: $10.1016 / j . c j c h e .2018 .06 .024$

[18] Nasser, G.A., Kurniawan, T., Tago, T., Bakare, I.A., Taniguchi, T., Nakasaka, Y., Masuda, T., Muraza, O. (2016). Cracking of nhexane over hierarchical MOR zeolites derived from natural minerals. Journal of the Taiwan Institute of Chemical Engineers, 61, 20-25. DOI: 10.1016/j.jtice.2015.11.025

[19] Dziedzicka, A., Sulikowski, B., RuggieroMikołajczyk. M. (2016). Catalytic and physicochemical properties of modified natural clinoptilolite. Catalysis Today, 259, 50-58. DOI: 10.1016/j.cattod.2015.04.039

[20] Nasser, G., Kurniawan, T., Miyake, K., Galadima, A., Hirota, Y., Nishiyama, N., Muraza, O. (2016). Dimethyl ether to olefins over dealuminated mordenite (MOR) zeolites derived from natural minerals. Journal of Natural Gas Science and Engineering, 28, 566-571. DOI: 10.1016/j.jngse.2015.12.032

[21] Waluyo, J., Richards, T.. Makertihartha, I., Susanto, H. (2017). Modification of Natural Zeolite as a Catalyst for Steam Reforming of Toluene. Asean Journal of Chemical Engineering, $17(1), \quad 37-45$. DOI: 10.22146/ajche.49564
[22] Waluyo, J., Makertihartha, I.G.B.N., Susanto, H. (2018). The effect of acid leaching time in modifying natural zeolite as catalyst for toluene steam reforming. MATEC Web of Conferences, 159, 02046 . DOI: 10.1051/matecconf/201815902046

[23] Chang, G., Yan, X., Qi, P., An, M., Hu, X. Guo, Q. (2018). Characteristics of reactivity and structures of palm kernel shell (PKS) biochar during $\mathrm{CO} 2 / \mathrm{H} 2 \mathrm{O}$ mixture gasification. Chinese Journal of Chemical Engineering, $26(10), \quad 2153-2161$. D O I : 10.1016/j.cjche.2018.03.003

[24] Putro, F.A., Pranolo, S.H., Waluyo, J., Setyawan, A. (2020). Thermodynamic study of palm kernel shell gasification for aggregate heating in an asphalt mixing plant. International Journal of Renewable Energy Development, $\quad 9(2), \quad 311-317$. do i : 10.14710/ijred.9.2.311-317

[25] Yusup, S., Khan, Z., Ahmad, M.M., Rashidi, N.A. (2014). Optimization of hydrogen production in in-situ catalytic adsorption (ICA) steam gasification based on Response Surface Methodology. Biomass and Bioenergy, 60, 98107. DOI: 10.1016/j.biombioe.2013.11.007

[26] Chiodo, V., Urbani, F., Zafarana, G., Prestipino, M., Galvagno, A., Maisano, S. (2017). Syngas production by catalytic steam gasification of citrus residues. International Journal of Hydrogen Energy. 42(46), 2804828055. DOI: 10.1016/j.ijhydene.2017.08.085

[27] Kirnbauer, F., Wilk, V., Hofbauer, H. (2013). Performance improvement of dual fluidized bed gasifiers by temperature reduction: The behavior of tar species in the product gas. Fuel, $108, \quad 534-542$. D O I : 10.1016/j.fuel.2012.11.065

[28] Zhang, B., Zhang, L., Yang, Z., Yan, Y., Pu, G., Guo, M. (2015). Hydrogen-rich gas production from wet biomass steam gasification with $\mathrm{CaO} / \mathrm{MgO}$. International Journal of $\mathrm{Hy}$ drogen Energy, 40(29), 8816-8823. DOI: 10.1016/j.ijhydene.2015.05.075

[29] Udomsirichakorn, J., Basu, P., Salam, P.A., Acharya, B. (2013). Effect of $\mathrm{CaO}$ on tar reforming to hydrogen-enriched gas with inprocess $\mathrm{CO} 2$ capture in a bubbling fluidized bed biomass steam gasifier. International Journal of Hydrogen Energy, 38(34), 1449514504. DOI: 10.1016/j.ijhydene.2013.09.055 